\title{
Erratum to: Impact of vitamin D fortified milk supplementation on vitamin $D$ status of healthy school children aged 10-14 years
}

\author{
R. K. Marwaha
}

Published online: 28 February 2014

(C) International Osteoporosis Foundation and National Osteoporosis Foundation 2014

Erratum to: Osteoporos Int

DOI 10.1007/s00198-013-2306-9

The statements regarding financial support and conflicts of interest should have made it clear that the financial assistance provided by DSM Nutritional Products to ILSI (India) for the project included monthly remuneration of the principal investigator.

The online version of the original article can be found at http://dx.doi.org/ 10.1007/s00198-013-2306-9.

R. K. Marwaha $(\bowtie)$

International Life Sciences Institute (ILSI), Flat No 17, Gautam

ApartmentsGautam Nagar New Delhi 110049, India

e-mail: marwaha_ramank@hotmail.com 